\title{
Head Circumference of the Newborn Ceylonese Baby
}

\author{
A. A. W. AMARASINGHE \\ From the General Hospital, Kandy, Ceylon, and the Department of Paediatrics, University of Ceylon
}

The measurement of the circumference of the head of the newborn child is important for the obstetrician, the paediatrician, and the anthropologist. No figures exist for the normal head circumference of the newborn Ceylonese child.

\section{Material and Methods}

The 813 infants subjected to measurement during the first week of life were born in the non-paying maternity section of the General Hospital, Kandy, during the four months from June to September 1965. Those infants with neonatal pathological conditions, such as hydrocephaly ( 1 case) and prematurity ( 28 cases), were not omitted. Infants with clinically recognizable moulding, caput succedaneum, or oedema of the scalp were, however, excluded. This series contained 4 ethnically distinct communities: the Sinhalese (673 cases), Tamils ( 75 cases), Muslims (48 cases), and Burghers (17 cases). In Ceylon, the standard for prematurity is considered to be $4 \mathrm{lb} .8 \mathrm{oz}$. (2141 g.) (Amarasinghe and Dissanayake, 1963).

The maximum circumference of the head was obtained by a line passing over the glabella and the pair of supraorbital ridges anteriorly and that part of the occiput posteriorly which gives maximal value. This supplied the fronto-occipital head circumference. Difficulties with measurement of the head circumference arise when the head has an abnormal shape as in hydrocephalus. Under these circumstances, measurement of the head size may best be made by a line crossing whatever points on the forehead and occiput give the maximal circumference.

All measurements were taken to the nearest $0.1 \mathrm{in}$. $(0.25 \mathrm{~cm}$.) with the tape unstretched but with all the slack eliminated. The same non-elastic tape-measure, checked for accuracy before use against a scale in inches, was employed throughout. All measurements were done by the same person.

\section{Results}

The head circumference of 813 babies ( 401 boys and 412 girls) was measured. The mean head circum-

Received January 24, 1966. ference was $13 \cdot 2$ in. $(33 \cdot 5 \mathrm{~cm}$.) (range $11 \cdot 0$ to $14 \cdot 8 \mathrm{in}$. $(28-37 \cdot 5 \mathrm{~cm})$.$) . For boys it was 13 \cdot 3$ in. $(33 \cdot 7 \mathrm{~cm}$.) and for girls it was $13 \cdot 1 \mathrm{in} .(33 \cdot 2 \mathrm{~cm}$.). The head circumference in $712(88 \%)$ babies was in the range of 12.0 to $13.9 \mathrm{in}$. $(30-35 \cdot 2 \mathrm{~cm}$.). There were only $16(28 \%)$ measuring less than $12 \cdot 0$ in. $(30 \mathrm{~cm}$.) and $85(10 \%)$ more than 13.9 in. ( $35 \mathrm{~cm}$.).

Analysis of the size of the head related to the birthweight revealed that the average head circumference for babies of birthweight less than $4 \mathrm{lb}$. (1814 g.) was $11.7 \mathrm{in}$. $(29.6 \mathrm{~cm}$.) (range 11.0 to $12 \cdot 4$ in. $(28-31 \mathrm{~cm}$.)), while the corresponding value for birthweight over $8 \mathrm{lb}$. (3628 g.) was $14 \cdot 1 \mathrm{in}$. $(36 \mathrm{~cm}$.) (range $13 \cdot 1$ to $15 \cdot 0$ in. $(33 \cdot 2-38 \mathrm{~cm}$.)). There was an increase in mean head size from 11.0

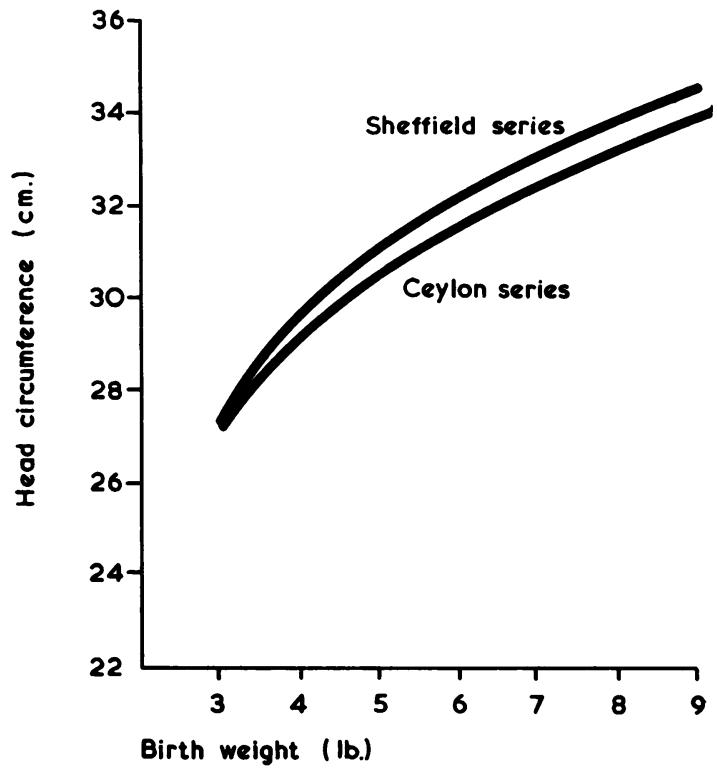

FIG.-This shows the increase in mean head size as mean birthweight increases, and compares these figures with a survey on Sheffield babies (O'Neill, 1961). 
TABLE I

Head Circumference according to Birth Weight

\begin{tabular}{|c|c|c|c|c|c|}
\hline \multirow{2}{*}{ Birth Weight } & \multirow{2}{*}{$\begin{array}{l}\text { No. of } \\
\text { Cases }\end{array}$} & \multicolumn{2}{|c|}{ Mean Head Circumference } & \multicolumn{2}{|c|}{ Range of Head Circumference } \\
\hline & & Inches & Cm. & Inches & Cm. \\
\hline $\begin{array}{c}\text { < } 3 \text { lb. } 15 \text { oz. }(<1785 \text { g. }) \\
4 \text { lb. }-4 \text { lb. } 15 \text { oz. }(1814-2239 \text { g. }) \\
5 \text { lb.-5 lb. } 7 \text { oz. }(2267-2465 \text { g.) } \\
5 \text { lb. } 8 \text { oz. }-5 \text { lb. } 15 \text { oz. }(2494-2692 \text { g. }) \\
6 \text { lb. }-6 \text { lb. } 15 \text { oz. }(2721-3146 \text { g. }) \\
7 \text { lb. }-7 \text { lb. } 15 \text { oz. }(3175-3600 \text { g. }) \\
>8 \text { lb. }(>3628 \text { g. })\end{array}$ & $\begin{array}{r}11 \\
65 \\
94 \\
116 \\
321 \\
163 \\
43\end{array}$ & $\begin{array}{l}11 \cdot 7 \\
12 \cdot 5 \\
12 \cdot 8 \\
13 \cdot 0 \\
13 \cdot 1 \\
13 \cdot 4 \\
14 \cdot 1\end{array}$ & $\begin{array}{l}29 \cdot 6 \\
31 \cdot 5 \\
32 \cdot 4 \\
33 \cdot 0 \\
33 \cdot 2 \\
34 \cdot 0 \\
35 \cdot 7\end{array}$ & $\begin{array}{l}11 \cdot 0-12 \cdot 4 \\
11 \cdot 4-13 \cdot 8 \\
12 \cdot 0-13 \cdot 8 \\
12 \cdot 2-13 \cdot 8 \\
11 \cdot 8-14 \cdot 1 \\
12 \cdot 9-14 \cdot 5 \\
13 \cdot 1-15 \cdot 0\end{array}$ & $\begin{array}{l}27 \cdot 9-31 \cdot 4 \\
28 \cdot 9-35 \cdot 0 \\
30 \cdot 4-35 \cdot 0 \\
30 \cdot 5-35 \cdot 0 \\
29 \cdot 9-35 \cdot 7 \\
32 \cdot 6-36 \cdot 7 \\
33 \cdot 2-38 \cdot 1\end{array}$ \\
\hline
\end{tabular}

to $15 \cdot 0$ in. $(28-38 \mathrm{~cm}$.) as birth weight increased (Table I and Fig.). The Figure also compares our findings with those of O'Neill (1961) who surveyed 901 white babies born in two maternity hospitals in Sheffield and Barnsley, Yorkshire. Her data are based on the maximum head circumference at age $7 \pm 1$ days.

\section{Discussion}

It is of interest to compare the mean head circumference of Ceylonese newborn babies-boys $13 \cdot 3$, girls $13 \cdot 1$ in. $(33 \cdot 7,33 \cdot 2 \mathrm{~cm}$.), with values from elsewhere. The mean head circumference of the newborn English boy is 13.6 in. $(34.5 \mathrm{~cm}$.) and of the girl 13.2 in. $(33.5 \mathrm{~cm}$.) (Norman, 1963). Measurement of newborn babies of North European ancestry living in Boston, U.S.A., mostly from families in the lower socio-economic brackets, showed a head circumference for males and females of $13.9(35.2 \mathrm{~cm}$.) and 13.7 in. $(34.7 \mathrm{~cm}$.), respectively (Nelson, 1964). These contrasting figures are stimulating anthropometric revelations.

\section{Summary}

The mean head circumference measurements of
813 Ceylonese newborn children was $13 \cdot 2$ in. $(33 \cdot 5$ $\mathrm{cm}$.). The head circumference was related to birth weight. The mean head circumference of Ceylonese newborn babies is less than that of babies of European ancestry.

I wish to thank Dr. John Lorber for directing me to carry out this investigation, Professor C. C. De Silva for his advice, Dr. H. A. Aponso in whose department the work reported was performed, and Dr. M. H. M. Hamza for allowing me to take measurements from children under his care. Dr. A. K. M. P. Jayasena and Dr. T. Dissanayake assisted me in the collection of data. I am grateful to the nursing staff of the maternity section of the General Hospital, Kandy, and the statistician, who preferred to remain anonymous, for their kind help.

\section{REFERENCES}

Amarasinghe, P. H., and Dissanayake, P. (1963). A search for the 'Ceylon premature baby'. Ceylon f. child Hlth, 1963, 35.

Nelson, W. E. (1964). Text Book of Pediatrics, 8th ed., pp. 25 and 55. Saunders, Philadelphia and London.

Norman, A. P. (1963). Congenital Abnormalities in Infancy, p. 53. Blackwell, Oxford.

O'Neill, E. M. (1961). Normal head growth and the prediction of head size in infantile hydrocephalus. Arch. Dis. Childh., 36, 241.

G. W. Chance and B. D. Bower 'Hypoglycaemia and Temporary Hyperglycaemia in Infants of Low Birth Weight for Maturity' (June 1966).

The sentence beginning on page 282 , column 1 , line 36 , should read 'Moreover, the oral route of glucose administration was reported by Creery (1963) as unsatisfactory in raising blood sugar, unless combined with hydrocortisone.' 